\title{
Implementation of the Al-Quran and Science Integration Approach at the Asajaya Regional Middle School
}

\author{
*Fadzila Binti Rahman', Mohd Aderi Che Noh ${ }^{2}$ \\ ${ }^{1}$ Universiti Pendidikan Sultan Idris, 35900 Tanjong Malim, Perak, Malaysia \\ ${ }^{2}$ Universiti Sains Islam Malaysia, 71800 Nilai, Negeri Sembilan, Malaysia \\ *lennfadz89@gmail.com
}

\begin{abstract}
Integration of Al-Quran and Science (PIQS) was introduced as a hub for enriching students' monotheism elements and playing a role in implementing the Higher Level Thinking Skills (KBAT) element. This study aims to identify the effectiveness of the PIQS approach on the achievement of KBAT and student perceptions in the field of faith. This study was carried out in four high schools in the Asajaya area, and a total of 80 second-year students were sampled for the study. This study uses a quasi-experimental design (Quasi-Experimental Design). The instruments used are pre-test and post-test, which consist of 10 subjective questions to measure students' $K B A T$ in the field of faith. In addition, probing questions were used to measure students' perceptions of the approach used between the control and experimental groups. A total of 40 students in the control group were taught using conventional methods, while 40 students in the experimental group were exposed to the PIQS approach. Data collection for pre and post exams was analyzed using the Statistical Package for the Social Science (SPSS) version 23.0 program. The study results were analyzed using an independent sample t-test to see if there was a significant difference in students' minimum KBAT achievement between the experimental group and the control group in the pre and post exams based on two different approaches in learning the field of faith. The study results show that the minimum post-test achievement for the treatment group is 29.22 higher than the control group, which is 21.57, and the difference between the two is 7.65 points. The investigation results also show that the minimum perception of the PIQS approach is high, which is 44.25, compared to the minimum perception of the traditional approach of 37.25. This study implies that it allows students to understand and explore the field of faith more clearly and can indirectly increase students' KBAT levels.
\end{abstract}

Integrasi Al-Quran dan Sains (PIQS) diperkenalkan sebagai hub penyuburan elemen tauhid pelajar di samping berperanan dalam menerapkan elemen Kemahiran Berfikir Aras Tinggi (KBAT). Kajian ini adalah bertujuan untuk mengenal pasti keberkesanan pendekatan PIQS terhadap pencapaian KBAT dan persepsi pelajar dalam bidang akidah. Kajian ini telah dijalankan di empat buah sekolah menengah daerah Asajaya dan seramai 80 orang pelajar tingkatan dua yang dijadikan sampel kajian. Kajian ini menggunakan reka bentuk kuasi-eksperimen (QuasiExperimental Design). Instrumen yang digunakan ialah soalan ujian pra dan ujian pos yang terdiri daripada 10 soalan subjektif untuk mengukur tahap 
pencapaian KBAT pelajar dalam bidang akidah. Selain itu, soal selidik digunakan untuk mengukur persepsi pelajar terhadap pendekatan yang digunakan antara kumpulan kawalan dan eksperimen. Seramai 40 orang pelajar kumpulan kawalan diajar dengan kaedah konvensional atau semasa sementara 40 orang pelajar kumpulan eksperimen diberikan pendedahan dengan pendekatan PIQS. Pengumpulan data ujian pra dan ujian pos dianalisis menggunakan program Statistical Package for the Social Science (SPSS) versi 23.0. Hasil kajian dianalisis menggunakan ujian-t sampel bebas (indipendent sample t-test) untuk melihat sama ada terdapat perbezaan yang signifikan bagi min pencapaian KBAT pelajar antara kumpulan eksperimen dan kumpulan kawalan dalam ujian pra dan pos berdasarkan kepada dua pendekatan yang berbeza dalam pembelajaran bidang akidah. Hasil dapatan kajian menunjukkan min pencapaian pos-ujian kumpulan rawatan adalah 29.22 lebih tinggi berbanding kumpulan kawalan iaitu 21.57 dan perbezaan min bagi kedua-duanya ialah 7.65 poin. Dapatan soal selidik pula menunjukkan min persepsi terhadap pendekatan PIQS adalah tinggi iaitu 44.25 berbanding min persepsi pendekatan tradisional 37.25. Implikasi daripada kajian ini membolehkan pelajar memahami dan mendalami bidang akidah dengan lebih jelas dan secara tidak tidak langsung dapat meningkatkan tahap KBAT pelajar.

Keywords: Implementation Approach, Integration of the Qur'an and Science, High School.

Received: November 2, 2021; Revised: November 27, 2021; Accepted: December 28, 2021

\section{INTRODUCTION}

Faith and adherence to religious life are the principles for fostering human beings, namely having perfect and balanced intellectual and spiritual intelligence (Majid, M. Z. A., 2006). This is in line with the Islamic Education Philosophy (FPI), which emphasizes balanced and harmonious human development from the physical, emotional, spiritual and intellectual aspects based on trust and obedience to the Creator based on the Qur'an and al-Sunnah (Ikhwan, 2018). In achieving the FPI, creed education is the central core for developing these human beings because it is the basis for the comprehensive implementation of the Shari'a in every individual Muslim (Othman, M. S. \& Kassim, 2017b).

Therefore, creed education requires an approach to teaching creed requires specific methods based on content pedagogical knowledge (PPK) based on the use of naqli (revelation) and aqli (reasonable) arguments as well as the shahadah genuine arguments contained in the Qur'an (Kasmo, 2000). This is because the belief in the faith requires clarity of thought and solid evidence, which can be accepted by reason willingly without coercion so that faith becomes firm (Hamzah et al., 2015). This case is also supported by (Majid, A., 2008) that aqidah belief is not formed easily because it is solid in the heart that requires clarity of mind that needs to be confirmed with naqliyyah and aqliyyah arguments to eliminate doubts.

Therefore, to achieve this matlamat, a transformation of the educational curriculum carried out by the Ministry of Education of Malaysia through the Standard Secondary School Curriculum (KSSM) is to integrate science and the Koran in Islamic Education 
textbooks in addition to emphasizing the concept of high-level thinking skills (Mansir, 2021). This effort is also to support the rise of the Islamization of knowledge among students worldwide, including Malaysia. It is an approach that works on the principles of philosophical thought of al-Quran science in the state education curriculum as a continuity towards creating a hadhari society that understands, appreciates, and develops knowledge in a comprehensive and integrated manner.

The arrival of the colonizers had caused the state education system to be anthropocentric, which led to the separation of religious education and academic education. In contrast, Islam had its realistic view of education, Syed Muhammad Naquib (Huringiin \& Azfathir, 2018). The impression is that religious education has received less attention because students are only introduced to divine issues, which are less associated with all aspects of human life. The description of the divine element is also often exposed in a blurry and rigid form so that it is difficult for students to understand and live it (Zakaria Din, 2005). This is because GPI is less exposed to science and humanities subjects, and they are less inclined to link the creed of monotheism with scientific and technological activities. As a result, the teaching delivered is not understood as a comprehensive philosophy of life (Al-Faruqi, 2015).

In the series of anthropocentric education systems, Muslim educators do not realise the unified concept expressed in the desire for the Philosophy of National Education. This is because, after almost 30 years of the integrated idea being absorbed in the education system, morals and morals are still hotly discussed issues (Siti Rashidah, Haslina and Zetty Nurlzuliana, 2016; Rohana Tan and Norhasni, 2016; Norina, WH Wan, et al. 2013; Zamri AR, 2013; Zakaria, SI, Ahmad Munawar, 2012; Fathiyah 2012). This is followed by spiritually oriented sciences such as creed and morals that are only taught through the mediation of reason (Nor Azlinda \& Maimun (2016). This illustrates that the education system in Malaysia today focuses more on aspects of motivation and does not educate conscience.

This fact is supported by Zetty Nurzuliana finding that the assessment method in Malaysia is oriented solely to aqli knowledge and is not balanced by touch rather than the arguments of the Qur'an. At the same time, the Qur'an is the primary source for both aspects (Rashed, 2016). The impression is the form of dualism and educational incompatibility between knowledge based on revelation and science and reason because one system only emphasizes the just aqli (modern science) science and the other system only emphasizes the just naqli sciences (Sidek Baba , 2012). The knowledge that is studied separately and too specialized can weaken student creativity. This situation makes them feel disciplined, and the learned subjects are essential. Unknowingly they have presented the information they want to learn. If the information received is limited, the learning process will also not thrive, and the understanding of the concept of revelation is blurred (Nordin \& Dan, 2002).

In transforming Islamic education, one of the components is increasing both the level of teacher knowledge and the ability of students to apply each learning content and so on to form students who are spiritually and intellectually balanced (Noor Hisham, 2011). But what is happening in schools now, GPI only masters religious knowledge compared to the understanding that goes beyond subject limits when teaching creed. Mohd Musnizam, Ab, supports this fact. (Halim \& Rohizan 2012) that GPI only teaches knowledge conducted while at the college training institute to carry out the teaching process in the darjah booth. Likewise, Islamic teachers who do not teach 
Islamic education only emphasize the discipline of reason, resulting in neglect of religious aspects. Thus, the result will be two different sets of young generations (Chaer et al., 2021). First, a group of students are too concerned with intellectual power without a high appreciation of religion and spirituality. Second, a group of religious experts cannot master spiritual disciplines (Nursyamira, Maimun and Nor Atikah 2016). These findings indicate that a continuous effort must be made to increase the level of mastery in various learning methods in the field of faith so that students' achievement of faith appreciation can be upgraded.

GPI is also often associated with dominating the learning process with traditional teaching styles, memorization, teacher-centred and assessment versus two-way interaction, causing weaknesses in the delivery of the teaching process in the darjah booth (Norliza et al. 2013; Noraini Omar, Mohd Aderi Che Noh, Mohd Isa Hamzah 2014). This causes the element of boredom, lack of understanding, inability to relate the contents of the Koran to the current situation and the stage of using very minimum thinking skills among students. Teacher teaching that is not impressive and effective will impact student achievement, even more so from the point of view of students' appreciation of the Koran as the kitabullah.

A study conducted by (Noraini \& Riduan, 2017; Kamarul Azmi et al., 2012) found that while teaching the creed, Islamic education teachers were more likely to use syarahan and lecture methods when compared to the technique of tadabbur verses of the Qur'an. These findings have supported the views of Ahmad Yunus \& Ab. Halim emphasized that the shariah rules for complex subjects such as aqidah are incompatible with low ratings. The impression is that the field of monotheism is considered difficult by students and fails to reach the matlamat to penetrate the soul of students (Yunus \& Ab. Halim, 2010). This also causes belief in aqidah to become increasingly difficult to form due to the lack of a deep understanding of the naqliyyah and aqliyyah arguments to eliminate any doubts they have.

Naziratul Izzati and Azmil Hashim conducted a study among Grade Four students at SMKA in Sabah in teaching the verse of understanding Al-Quran, and al-Sunnah (PQS) education found that students were studying the Koran but did not understand the meaning of the surah (Izzati \& Hashim 2016). They are being taught. The implication is that the minimum stage of appreciation of the faith for the practice aspect of the student is simple. This explains that the approach of making disciples of the Qur'an alone is not able to shape students' personalities with noble morals because it also requires the use of scientific theory and evidence to sway the arguments of the naqli and aqli. In line with Al-Ghazali's 1988 view to produce students capable of reflecting, generating ideas and educating every creation of Allah, GPI should use an approach that can train students to use reason optimally in teaching the field of faith (Noor Shakirah, 2006).

The creed's teaching should produce students who try to present evidence that is easy to understand, point out ideas, use the verses of the Qur'an related to the title and encourage the maximum use of reason. Investigators believe this approach promotes the process of higher-order thinking skills (KBAT) because students have the opportunity to explore the relationship between al-Quran and science more deeply. However, providing KBAT-oriented teaching is a challenge to GPI. The results of the study by Amir Khan, Aderi Che Noh and Tarmimi Hussein (2016) show that the GPI is still unclear about the concept and purpose of KBAT and mistakenly distinguishes 
KBAT carried out with KBAT PdP or KBAT items for the assessment of Islamic Education (Anwar, 2021). This study has supported (Hasmaliza Hassan, 2016; Ainol Madziah, 2015) and showed that GPIs have difficulty incorporating KBAT in their PdP processes because they cannot understand the concepts and topics of thinking skills (Talhah Ajmain \& Mohd Aderi, 2016).

This indirectly affects students' KBAT because, according to (Amabile et al. 2010), to produce students who can think and have the ability to solve problems, teacher pedagogy should emphasize the provision of complex tasks that are highly cognitive. The investigators believe that the power of students to apply each content of the contents of the students has a relationship with the ability of students to practice KBAT elements in daily life. This view refers to the writing of Syed Hossein Nasr, who pioneered Contemporary Islamic Thought activating the notion of ijtihad, namely the ability of students to interpret the meaning of the Koran by using a mind that is guided by the science of divinity and translating it into real life (Syarif Hidayatullah, 2018). Therefore, it is essential to explore the pedagogy that teachers can practise to improve KBAT among students. In addition to developing cognitive KBAT in Islamic education, it plays a vital role in shaping students to appreciate faith and practice in daily life based on the Koran and As-Sunnah (Rashed et al., 2016).

So it becomes necessary for this balance to be practised in every student. This is a need for KBAT to be implemented in Islamic education and application to other subjects such as science and mathematics (Huri et al., 2012). Fatimah explains that students should be exposed to faith rather than the perspective of rational thinking through the confirmation of modern scientific knowledge (Abdullah, 2005). In addition, if the science and scientific studies aim to support the scope of the science of faith, such as believing in unseen things such as ratifying the existence and power of Allah SWT and the scientific value of religious law. The integration of creed and science can increase students' awareness of the presence of Allah and draw them closer to Him. Through exploration of science, he is pushing towards the enrichment of the element of monotheism, which is to show a sign of the oneness of Allah SWT (Nordin \& Dan, 2002).

In conclusion, the general and specific problems raised as above encourage researchers to conduct studies on the integration of the Qur'an and Science (PAS) into creed education, helping to expand knowledge again in addition to promoting KBAT elements in students. From this study, we will also be able to assess the relationship between the stages of using this approach during the $\mathrm{P} \& \mathrm{P}$ in addressing the problems stated.

\section{The Role of GPI in the Approach to the Integration of the Quran and Science}

Al-Syaibani states several principles towards effective teaching and learning planning of Islamic Education. Teachers should identify the motivations, needs and interests of students, ensure the purpose of learning, know the level of maturity of students to learn, know the differences of individual differences between students, provide opportunities for practical experience, observe understanding and know the relationships, integration of knowledge and its continuity, originality, renewal and freedom of thought and make the educational process an enjoyable experience for students. Eggen and Kauchak stated the importance of lesson planning as presented by Philips (Eggen, 2012). Aspects that need to be seen are the determination of learning objectives, learning activities that can help students achieve the purposes, and 
selecting appropriate assessments to determine goals. He also stressed that there needs to be alignment and matching between learning objectives, learning activities and assessment.

Therefore, GPI must take into account the factors of the existence of the teaching and education planning process of the faith is aimed at producing students who master religious skills that are not separate from the science process, master thinking skills with a combination of remembrance and have the creative and innovative ability in problem-solving. The goal-setting of the teaching and learning process of the faith is to develop the motivation of confidence in the hearts of students. Cause of religion refers to the drive to learn because it can see meaning in teaching and learning based on a sense of responsibility to Allah SWT. Thus, the target of the teaching and learning process by GPI is the cognitive organ aqal kulli (intellect) and the mental organ of the heart in addition to the cognitive organ aqal juzui (rational), which is subject to revelation (Salleh et al., 2011).

Teaching also has specific characteristics: the teacher is an instructor, and the student is a student. It can be carried out with teacher-centred, student-centred and teacherpupil combination and resource-centred activities. Thus, this process will involve twoway interaction. The role of GPI in implementing the integration of the Quran and science in the field of faith is based on a combination of the Needham 5 Phase model developed by Richard Needham in the United Kingdom in 1987. This model has been used to build students' knowledge by testing ideas and approaches based on knowledge and experience. Existing, applying new situations and integrating the new knowledge gained with the existing intellectual constructs of science subjects. The Needham model consists of five phases, namely the orientation phase, the idea generation phase, the idea restructuring phase, the idea application phase and the reflection phase. This design is also based on the term critical thinking skills contained in the Qur'an, namely tafqih, tafakkur, ta'qil, tadabbur and tadhakkur (Kadri, 2015).

Table 1. Design features in the Quran and science integration approach for each component in the Needham 5 Phase model (Richard, 1987)

\section{Components Design in the Al-Quran and Science Integration Approach}

\begin{tabular}{ll}
\hline $\begin{array}{l}\text { Orientation } \\
\text { (Tafqih) }\end{array}$ & $\circ$ Attract the attention and interest of students. \\
& $\begin{array}{l}\text { Motivate students so that they continue to be interested in } \\
\text { the teaching that takes place. }\end{array}$ \\
\hline $\begin{array}{l}\text { Pencetusan idea } \\
\text { (Tafakkur) }\end{array}$ & $\begin{array}{l}\text { The process of interpretation or representation of natural } \\
\text { phenomena as signs of the greatness of Allah SWT. }\end{array}$ \\
& $\circ$ Using inquiry methods to delve and investigate through the \\
evidence of the Qur'an and science
\end{tabular}

Restructuring of $\circ$ Modify students' alternative frameworks to scientific ideas.

ideas $\quad$ Make definitions, explain concepts, ask questions about (Ta'qil) further explanations and ask for justifications and explanations from students.

Application $\quad \circ$ Identify the fact of human creation, the fact of the creation of Ideas nature based on the verses of the Quran and the theory of 


\begin{tabular}{ll}
\hline (Tadabbur) & science. \\
\hline Reflection & $\circ$ Assess student comprehension \\
(Tadhakkur $)$ & $\circ \begin{array}{l}\text { Pupils compare original knowledge with new knowledge and } \\
\text { reflect back on the learning process that caused the change to } \\
\text { their ideas. }\end{array}$ \\
& $\circ \begin{array}{l}\text { Remembering, mentioning, remembering, saying, praising, } \\
\text { magnifying the power of Allah SWT. }\end{array}$ \\
\hline
\end{tabular}

In the orientation phase (tafqih) refers to understanding and comprehending the signs of Allah SWT's power that exist in nature, including the heavens, earth, self and human soul, as well as contemplating the sunnah of Allah SWT as stated in His words in surah al-A'raf which means:

"And verily We have appointed for hell many of the jinn and men who have hearts (but) do not want to understand (the verses of Allah), and who have eyes (but) do not wish to see there (proof of the Oneness of Allah) and who have ears (but) did not want to listen to him (teachings and advice); they are like cattle, even more astray; they are the heedless ones." (Q.S. al-A'raf 7: 179).

The meaning of the above verse is the term yafqahun emphasizing the effort to understand and know the verses of Allah SWT through deep thought to get guidance or truth (Wan Mat \& Norkhairiah, 2011). Therefore, the GPI should provide a suitable learning environment during this phase to stimulate and arouse students' interest in the lesson. Various ways are done to get the attention of students. The content of the field of knowledge presented is also significant to be mastered by teachers and technical preparation such as the use of Teaching Aids (BBM), and provide a conducive environment when the $\mathrm{P} \& \mathrm{P}$ process is implemented. Regarding the provision of stimulus materials, teachers need to design materials that activate students' senses, encourage students to think and stimulate innovation (Ramayulis, 2012). Teachers are encouraged to create their training materials because teachers can adapt the training materials to the background of students and the desired thinking process (Muhd \& Hasan, 2011).

The second phase, idea generation (tafakkur), uses the intellect in a matter and organises a known problem to know something previously unknown (Mustafa, 1972). It is a process of thinking by analyzing the signs of kawniyyah that exist in the vast universe and also the miracles of the verses of the Qur'an as mentioned in the words of Allah SWT in surah ar-Ra'd, which means:

"And He it is Who made the earth wide, and made therein mountains (firm) and rivers (flowing). And of every kind of fruit, He made for it pairs: two. It also protects day with night alternating. Indeed, all of them contain signs of God's power for a people who (want) to think" (Q.S. ar-Ra'd 13: 3).

Pupils are urged to think about various things such as plants, crops, fruits and flowers that Allah SWT animates with the fall of rain, the spread of the earth for human beings with mountains and rivers that exist on it, as well as the events of night and day that humans go through it every day (Kadri, 2015). This means that thinking and analyzing must be done all the time because, by thinking, one can remember Allah SWT and take lessons from him. 
GPIs can also carry out various forms of activities such as group discussions, use the concept map method, and make reports by linking existing knowledge with new knowledge that they will learn. GPI needs to play a role as a facilitator of educating the student's soul to understand and always remember that all the events of this universe are under the governance of Allah SWT. This contemplation phase leads to the urge to study and research not only within the limits of real things but also to have guidance from the Almighty Creator on the proper way of management. It is so that there is a balanced understanding that an event belongs to Allah SWT. Human beings are only given the trust to manage it well and correctly. Imam Fakhrul Razi claims that those who analyze and believe in the Oneness of God by using their intellect (thought) will reach out to creative and innovative thinking and have flexibility in adapting to change (Aswadi, 2012).

Whereas, in the phase of idea restructuring (Ta'qil), it refers to the process of giving understanding and understanding that is not only the fundamental aspects and can be seen through the senses such as this world but understanding abstract things such as the concept of divinity, the hereafter, paradise hell and reward sin (Asy'arie, 2002). Allah SWT confirms this matter as in His word through surah Al-Baqarah, which means:

"Should you tell people to do good while you forget yourselves; even though you all read the Book of Allah, do you not understand?” (Q.S. al-Baqarah 2: 44).

Accordingly, GPIs should provide activities or give structured assignments to enable students to challenge their original ideas or peers' ideas and build their own more meaningful and effective knowledge structures through Quranic sources and scientific theories. In addition, GPI will expose students to contextual learning to be sensitive and sensitive to the surrounding environment. This encouragement should be followed by reading, sharing knowledge and information, analyzing and comparing data from Quranic sources, Sunnah, scholarly materials etc., which ultimately puts a subject or issue of thought into the student's perspective.

Seeing and responding to something based on the perspective of thinking can further increase knowledge and make something information and insights develop towards critical thinking. Critical thinking is broadening thinking by looking at various factors and data as the reason something happens in concluding. The GPI should emphasize the use of scientific terms derived from the Quran. This strategy requires the GPI to know the origins of scientific terms used in the field of faith to enable the GPI to relate its teachings to the Islamic scientists who discovered the word in particular and to Islamic civilization in general (Muhayat, 2020). With this, a student can understand all these meanings and connect concrete and fundamental concepts to balance the life of this world and the hereafter (Asy'arie, 2002).

The fourth phase is the application of ideas (Tadabbur) which is an effort to think about the effects or consequences of each problem. It also involves the action of seeing the beginning and the end, then going back to doing research and study many times (al-Qaradawi, 1998). By tadabbur al-Quran, students can apply the problemsolving methods outlined in the al-Quran and take lessons and teachings from it. Continuous effort and study will produce good results and gain high confidence in choosing the solution (Kadri, 2015).

Imam al-Ghazali, through epistemological theory, has interpreted the word tadabbur as a process of reasoning that is a qualification that allows an individual to respond to 
knowledge and think about something that has been known and studied. Researchers argue that the Tadabbur element is the highest level in critical skills because Ibn Khaldun, in his book of thought Al-Muqaddimah, who explains the highest feature in thinking skills, is Asbab wal Musabab (Kassim \& Tamuri, 2010);(Othman, M. S. \& Kassim, 2017a). The stage is the student's ability to give an impression of the existence of something through various intelligence, differences of cause and effect. This situation can create a new understanding and encourage the inquiry process in students. Through that stage, students can reach a sense of human reality by using a quality mind and a strong soul.

Next is the phase of reflection (tadhakkur), meaning the repetition in the heart of what has been known to strengthen further and stabilize it so that it does not disappear or be erased from the heart. About the context of problem-solving, the effort to think about the blessings and signs of his greatness through nature, dhikr by mentioning the names of Allah SWT and the like will be able to solve the people's problems. This is because all the causes of issues come from Allah SWT, and only He has the power to solve problems. Returning to the remembrance of Allah SWT is the best way to strengthen faith, obtain happiness and free oneself from the issues of the world (al-Qaradawi, 1998).

As a result of the five-phase learning process, the role of GPI as an evaluator after students experience the integration approach of the Qur'an and science is students who implement the concept of monotheism in their lives and have the characteristics of Muslim science; able to witness the truths of the natural world and the supernatural; have unity of reason and revelation; perform a combination of thought and remembrance. However, the evaluation process that measures these characteristics considers the time factor because the development of Muslim scientists takes a long time. Apart from that, the skills of thinking and remembrance the nurturing of faith require the GPI to evaluate a student personally and continuously (Khalijah, 2007). Therefore, GPI should understand the assessment process from the aspect of assessment methods when teaching formal, informal and non-formal and from the part of criteria to be assessed and having a sharp perception so that it can distinguish the spiritual achievement of one student from another.

\section{METHOD}

The researcher used a quasi-experimental design to compare the level of achievement between the treatment group using the PIQS approach while the control group used the usual method (lecture). The duration of this study is proposed for four weeks and four Islamic Education teachers in schools, namely SMK Asajaya (X1), SMK Halata (X1), SMK Sadong Hilir (X2) and SMK Sadong Jaya (X2). X1 and X2 are the learning methods assigned to the Treatment Group and the Control Group. The teachers involved conducted teaching for a selected group of students, i.e. a homogeneous control group and treatment group, where the control group received topic learning in the field of faith using a conventional approach. In contrast, the treatment group received the same topic learning using the PIQS approach. Both groups were given pre-tests before the study was conducted, and post-tests were given to the treatment group. Questionnaires were also used to see to what extent the effectiveness of the PIQS approach could improve the level of students' perceptions in the field of faith. 
Table 2. Pre and Post Test Design of Treatment and Control Groups

\begin{tabular}{cccc}
\hline & Pre-Exam & Method & Post Exam \\
\hline Treatment group & $\mathrm{U} 1$ & $\mathrm{X} 1$ & $\mathrm{U} 2$ \\
Control group & $\mathrm{U} 3$ & $\mathrm{X} 2$ & $\mathrm{U} 4$ \\
\hline
\end{tabular}

In the design of this study (Table 2), U1 and U3 were pre-test implementations. U2 and $\mathrm{U} 4$ are posted test implementations. At the same time, $\mathrm{X} 1$ and $\mathrm{X} 2$ are the learning methods given on the Treatment Group and the Control Group. Pre-tests were conducted to see the equivalence of existing knowledge between groups, as both students were randomly selected. Post-test was born after both groups finished following the teaching method that is for the Treatment Group. Students were exposed to the PIQS approach and the Control Group using the lecture approach. Both groups received the same teaching materials and the amount of teaching time was also the same.

The study's respondents consisted of 80 students who have similar characteristics in terms of age and their achievement at the UPSR level. They are from two students in four secondary schools in Asajaya district, Sarawak and 20 respondents were recruited for each school. This can help ensure a balance in terms of achievement between the two study groups. A total of 40 people were grouped into the control group, while another 40 were grouped into the treatment group.

The validity and reliability of the instrument are fundamental to maintaining the accuracy of the device from being prone to defects. The higher the value and level of validity and reliability of the instrument, the more accurate the data obtained to produce a good and quality study (Majid Konting, 2000). The survey conducted by the researcher has had reliability and validity because the survey showed a random selection of students and achievement tests taken from the evaluation questions of the Islamic Education textbook form 2 (KSSM) year 2018.

The data collected consisted of achievement tests (pre and post-tests). Data were analyzed using Statistical Package for Social Science software system, SPSS Windows Release 22.0. Pre and post-test data were analyzed through inferential statistics, that is, t-test using an independent menu to see the difference in the achievement of KBAT between treatment group students who use the PIQS approach with control group students who use the lecture approach. If the results of t-test analysis on student achievement using PIQS approach and lecture approach show significant difference with high inference score with $\mathrm{p}$-value $<05$, then student acceptance is positive. If the t-test analysis of student achievement is the opposite, it proves that students ' favour of the PIQS approach and lectures is negative.

Meanwhile, the data related to the questionnaire were collected according to groups, namely the treatment group and the control group. The data of this questionnaire were analyzed using descriptive analysis to obtain mean values related to students' perceptions for both groups, namely the treatment group and the control group. The mean value analysis was conducted to see the differences in the aspects of perception between the treatment group students who used the PIQS approach and the control group students who used the traditional approach. The analysis of mean values related to the PIQS approach and the conventional approach will show a positive student acceptance if the overall mean of the questionnaire items exceeds the value of 3 (the 
value of the level of agreement). However, if the general standard of the questionnaire items is less than a value of 3 , it indicates that student acceptance is negative. Analytical data related to students' favour of the PIQS approach and traditional approaches for this field of faith will be seen in the findings section later (Ikhwan, 2021).

\section{RESULT AND DISCUSSION}

To determine the level of student KBAT achievement, the researcher has categorized each KBAT score according to the question mark scoring scheme for Islamic Education KBAT items set by the Malaysian Examinations Board 2012 with four scoring categories as in Table 3.

Table 2. Scoring of Marks

\begin{tabular}{ccl}
\hline Score & Bookmark & \multicolumn{3}{c}{ Descriptor } \\
\hline Brilliant & $36-40$ & $\begin{array}{l}\text { State facts with clear and complete } \\
\text { descriptions and supported by arguments/ } \\
\text { propositions/ proverbs/ allusions/ effects and } \\
\text { have conclusions, conclusions or suggestions. }\end{array}$ \\
\hline Satisfying & $28-35$ & $\begin{array}{l}\text { State facts with clear and complete } \\
\text { descriptions and supported by arguments/ } \\
\text { propositions/ proverbs/allusions/ effects. }\end{array}$ \\
\hline Good & $19-27$ & State facts with a brief description \\
\hline Satisfactory stage & $0-18$ & State facts only \\
\hline
\end{tabular}

Source: Malaysian Examinations Board (2012)

\section{T Test Analysis of Student Achievement and Interest}

Hypothesis 1: There is no significant difference in the mean measure of pretest achievement of KBAT form two students in the field of faith between the treatment group and the control group.

Table 4. Mean t-test of Pretest and Posttest of HOB achievement of students in the field of faith between the Treatment Group and the Control Group

\begin{tabular}{ccccccc}
\hline Variables & Gathering & Min & $\begin{array}{c}\text { Standard } \\
\text { deviation }\end{array}$ & DK (n-2) & $\boldsymbol{t}$ value & $\boldsymbol{p}$ value \\
\hline Pre-test & Treatment & 20.95 & 4.00609 & 78 & 0.640 & 0.524 \\
& Control & 20.35 & 4.36507 & & & \\
\hline \multirow{2}{*}{ Post-test } & Treatment & 29.22 & 4.06036 & 78 & 8.930 & 0.000 \\
& Control & 21.57 & 3.58692 & & & \\
\hline
\end{tabular}

Significant at the value of alpha (á) $=0.05$ 
Table 3: Based on table 4, the mean of pretest achievement for the treatment and control groups is at a reasonable level which is the treatment group 20.95, while the mean achievement for the control group is 20.35 , and the mean difference for both is 2.0 points. A t-test is said to be significant when the probability value of $\mathrm{p}$ is less than the value of the alpha level (á). The test results show that the probability value of $p$ is 0.534 , and the significance level value of alpha (á) is 0.05 . So the probability value of $\mathrm{p}$ is higher than the significance level value of alpha (á) which is $0.524>0.05$. Thus, the study results found that there was no significant difference in the mean reading of the pretest of students' HOTS achievement in the field of faith between the treatment group and the control group.

While the post-test achievement of KBAT in the field of faith for the treatment group is at a satisfactory level is 29.22 , the mean post-test achievement for the control group is still at a good level of 21.57, and the mean difference for both is 7.65 points. A t-test is said to be significant when the probability value of $p$ is less than the value of the alpha level (á). The results of the achievement post-test showed that the probability value of $\mathrm{p}$ was 0.000 , and the significance level value of alpha (á) was 0.05 . So the probability value of $\mathrm{p}$ is lower than the significance level value of alpha (á) which is $.000<.05$. Thus, the study results found a significant difference in the mean post-test reading of achievement between the treatment group and the control group. Therefore, hypothesis 1 , which is a substantial difference in the mean post-test readings of HOB achievement between the treatment and control groups, is accepted. Statistically, the pre-test means reading with the post-test mean reading of KBAT achievement in the field of faith for the treatment group was higher by 7.65 points than the control group.

\section{The Formulation of Descriptive Analysis Examines Students' Perceptions of PIQS in The Field of Faith}

The following are data for the effect of the PIQS approach and the traditional approach on the perceptions of students in the field of form two faith. Table 5 shows the descriptive analysis of respondents according to students' perceptions of trust after using the PIQS approach and the traditional approach. Based on table 4, statistically, the overall mean test value for students' perceptions in the field of faith for the treatment group is 44.25 is higher than the post-test mean of interest for the control group is 37.25 , and the mean difference for both is 7.0 points.

Table 5. Mean Perceptions of Treatment Students and Control Students

\begin{tabular}{llcccc}
\hline \multirow{2}{*}{ No. } & \multicolumn{1}{c}{ Student Perception } & \multicolumn{2}{c}{ Treatment Group } & \multicolumn{2}{c}{ Control Group } \\
\cline { 3 - 6 } & & Min & S.P & Min & S.P \\
\hline 1 & Help me realize the greatness of Allah & 4.350 & 0.6621 & 3.600 & 0.777 \\
\hline 2 & Help me admire the power of Allah & 4.225 & 0.8316 & 4.400 & 0.671 \\
\hline 3 & $\begin{array}{l}\text { Motivates me to recite verses of the } \\
\text { Qur'an }\end{array}$ & 4.525 & 0.5057 & 3.225 & 0.919 \\
\hline 4 & $\begin{array}{l}\text { Acknowledging that science is also } \\
\text { contained in the Quran }\end{array}$ & 4.425 & 0.6359 & 3.900 & 0.810 \\
\hline
\end{tabular}




\begin{tabular}{llllll}
\hline 5 & $\begin{array}{l}\text { Interesting to continue to follow the PdP } \\
\text { process }\end{array}$ & 4.525 & 0.5541 & 3.225 & 0.919 \\
\hline $6 \quad \begin{array}{l}\text { Encourage to surf the internet related to } \\
\text { the relationship between science and the } \\
\text { Quran }\end{array}$ & 4.550 & 0.5038 & 4.400 & 0.671 \\
\hline $7 \quad \begin{array}{l}\text { The PQIS approach encourages self - } \\
\text { review }\end{array}$ & 4.625 & 0.5856 & 3.600 & 0.777 \\
\hline $8 \quad \begin{array}{l}\text { Motivate to explore science in the } \\
\text { Quran }\end{array}$ & 4.225 & 0.7670 & 3.900 & 0.810 \\
\hline $9 \quad \begin{array}{l}\text { Encourages high -level thinking } \\
\text { Aware of the importance of the }\end{array}$ & 4.475 & 0.5057 & 3.750 & 0.926 \\
\hline $\begin{array}{l}\text { Islamization of science } \\
\text { Overall Min }\end{array}$ & 44.25 & 0.6793 & 3.225 & 0.919 \\
\hline
\end{tabular}

Hypothesis 2: There is no significant difference in the perceptions of students using the PIQS approach with traditional approaches in the field of faith.

Table 6. Mean t-test of Posttest of Interest of Year 4 students in the topic of material properties between the Treatment Group and the Control Group

\begin{tabular}{ccccccc}
\hline Variables & Group & Min & $\begin{array}{c}\text { Standard } \\
\text { Deviation }\end{array}$ & DK (n-2) & $\boldsymbol{t}$ value & $\begin{array}{c}\boldsymbol{p} \\
\text { value }\end{array}$ \\
\hline Post Perception & Treatment & 44.25 & 2.8092 & 78 & 9.071 & 0.040 \\
& Control & 37.25 & 4.1602 & & & \\
\hline
\end{tabular}

A t-test is said to be significant when the probability value of $p$ is less than the value of the alpha level (á). The results of the interest post-test showed that the probability value of $\mathrm{p}$ was 0.04 , and the significance level value of alpha (á) was 0.05 . So the probability value of $\mathrm{p}$ was lower than the significance level value of alpha (á) which is $0.04<.05$. Thus, the study results found a significant difference in the mean post-test reading of interest between the treatment group and the control group. Therefore, hypothesis 2, that there is a substantial difference in the mean task of perceptual test between the treatment and control groups, is accepted. Statistically, the pre-test mean reading with the post-test mean reading of students for the treatment group was higher by 0.72 points compared to the control group.

The analysis of data obtained through pre-tests showed that students in the treatment group and control group were to have similar achievements or abilities in the field of faith at the initial stage of the study. Results The mean cumulative accomplishment of the pre-test for the treatment group was 20.95, while the mean cumulative achievement for the control group was 20.35. The mean difference between the two groups was 0.6 . The highest post-test score for the treatment group was $28 \%$, while the highest score for the control group was $36 \%$. The improvement in scores shown 
found that mind maps are a handy tool for improving student achievement (Morgan, 2009).

Further data analysis showed that the mean difference of achievement in the post-test for the treatment and control groups was 29.22 and 21.57. The mean difference between the two groups was 7.65. This thus indicates that the achievement of KBAT for the field of faith is better by using PQIS compared to the traditional approach. Student achievement is particularly significant when students are directly involved in synthesizing science-related articles in the Qur'an, as has been evidenced through the increase in mean achievement in the Post Test. This shows that there is effective communication between teachers and students in this study which is also adapted in the study of (Othman, M. F. et al., 2017) have found that the appreciation of the science of the Qur'an can stimulate the mind to think at a high level through the PQIS approach because human beings need to go through the process of tadhakkur, ta'qil and tadabbur of the verses of the Qur'an while conducting studies and research on the occurrence of self and the environment.

The analysis for each item according to the scoring of Islamic Education KBAT item scores showed an increase in the achievement scores of the treatment group using PQIS compared to the control group using the traditional approach. These findings support the study of (Rashed, 2016);(Tamuri \& Yusof, 2010); (Rashed et al., 2016) the exploration of scientific knowledge contained in the verses of the Quran should be integrated into PdP because it serves to motivate students to explore various fields of knowledge contained in the Quran. In addition, these results have also supported the opinion that has been put forward by (Nur Hazizi, 2017);(Iksan et al., 2016). The findings found that the students were aware of the greatness of Allah Almighty, and they greatly admired the greatness of Allah when they were instructed to search for material related to the topic of the water cycle on the internet and link it by finding the meaning of verses using tafsir al-Quran. This clearly shows that the PQIS approach carried out by researchers can increase students' reverence for the greatness of Allah SWT as well as encourage critical thinking among students.

The questionnaire results found that each question item answered by the respondents of the treatment group was positive from item 1 to item 10. A high mean value was obtained from the perception post of students of the treatment group compared to students of the control group because students have a higher perception of the PQIS approach when compared with the traditional approach. This proves that the PQIS approach gives a high perception to students during the PdP process of faith. These findings support Ili Atiqah \& Ruslin, who found that teacher influence plays a role in producing fun lessons to train students to think critically when teachers ask high-level questions to students (Atiqah \& Ruslin, 2016). This is because the KBAT approach was found to reduce boredom towards the topics discussed. Therefore, teachers are a critical factor in teaching because students' readiness in the elements of HOTS depends a lot on teachers through questioning techniques and high-level training to encourage and stimulate students to think.

\section{CONCLUSION}

From the results of research and data analysis conducted, it can be concluded that the use of the PIQS approach in teaching and learning faith has been able to help in improving the achievement of HOTS and student perception in the field of faith on 
form two students in Asajaya District secondary schools, Sarawak. The results of this study can also be used as a benchmark or picture to us, especially Islamic Education teachers, on the extent to which the effectiveness of the use of PIQS can unearth the elements of HOTS or HOTS applied in teaching and learning. In addition, this PIQS can help students learn more meaningful and apply what is known in daily life. In addition, through the approach of the Qur'an and science will produce people who master the elements of tadhakkur, ta'qil, tafakkur, tafqih and tadabbur in analyzing the verses of the Qur'an. Human interaction with the universe through the Qur'an, intellect and senses, observation, observation and experimentation Science can trigger various types of knowledge. It can increase piety and faith in Allah SWT. The results shown in this study can be used as a guide to teachers, schools and stakeholders to improve the performance and interest of students, especially in learning Islamic Education PIQS approach in teaching and learning in this study can help improve student achievement and perception. In the field of faith.

\section{REFERENCES}

[1] Abdullah, F. (2005). Teaching Islamic Theology In The Era of Globalization. In Proceedings International Seminar Religious In The Muslim World: Challenges and Prospect. Kuala Lumpur: International Islamic University.

[2] Al-Faruqi, A. R. H. (2015). Konsep Ilmu dalam Islam. Jurnal KALIMAH, 13(2).

[3] Anwar, S. (2021). Evaluasi Pendidikan Menuju Insan Kamil Perspektif Filsafat Islam. Jurnal Pendidikan Nusantara, 1(1), 62-76.

[4] Aswadi. (2012). Konsep Syifa' dalam Alquran; Kajian Tafsir Mafatih al-Ghaib karya Fakhruddin al-Razi. Jakarta: Kementerian Agama RI.

[5] Asy`arie, M. (2002). Filsafat Ilmu: Sunnah Nabi dalam Berpikir. Yogyakarta: Lembaga Studi Filsafat Islam (LESFI).

[6] Chaer, M. T., Rochmah, E. Y., \& Sukatin. (2021). Education Based on Local Wisdom. JIE: Journal of Islamic Edication, 6(2), 145-157.

[7] Eggen, P. D. K. (2012). Strategi dan Model Pembelajaran. Jakarta: PT Indeks.

[8] Hamzah, M. S., Laki, A. F., Embong, R., \& Murshidah, N. (2015). Penerapan Akidah Dalam Dasar Pendidikan Malaysia: Analisis Terhadap Falsafah Pendidikan Negara Dan Islam Hadhari. Project: Penerapan Akidah Dalam Dasar Pendidikan Malaysia, Bil(9).

[9] Huri, H. Z., Makmor-Bakry, M., Hashim, R., Mustafa, N., \& Ngah, W. Z. W. (2012). Optimisation of glycaemic control during episodes of severe/acute hyperglycaemia in patients with type 2 diabetes mellitus. Springer, 34, 863-870.

[10] Huringiin, N., \& Azfathir, H. N. (2018). he Concept of Syed Muhammad Naquib al-Attas on De-Westernization and its Relevancy toward Islamization of Knowledge. Kalimah: Jurnal Studi Agama dan Pemikiran Islam, 16(2).

[11]Ikhwan, A. (2018). Filsafat Pendidikan Islam: Memahami Prinsip Dasar. Yogyakarta: Diandra Kreatif.

[12] Ikhwan, A. (2021). Metode Penelitian Dasar (Mengenal Model Penelitian dan Sistematikanya). Tulungagung: STAI Muhammadiyah Tulungagung. 
[13] Iksan, Z. H., Saper, M. N., \& Rashed, Z. N. (2016). Integration of Tawhidic Science through Lesson Study Approach in teaching and learning science or Islamic study. Tinta Artikulasi Membina Ummah, 2(1), 40 - 50.

[14] Kadri, Z. (2015). Elemen Pemikiran Kritis Menurut Perspektif Al-Quran: Kajian Surah Al-Rum. Universiti Malaya.

[15] Kasmo, M. A. (2000). Pemantapan Akidah Menerusi Penghayatan Sains dalam alQur'an. Tesis Ph.D.Bangi. Fakulti Pendidikan UKM.

[16] Kassim, A. Y., \& Tamuri, A. H. (2010). Pengetahuan Pedagogikal Kandungan (PPK) Pengajaran Akidah: Kajian Kes Guru Cemerlang Pendidikan Islam. Journal Of Islamic Arabic Education, 2(2), 13-20.

[17] Majid, A. (2008). Perencanaan Pembelajaran, Mengembangkan Standar Kompetensi Guru. Jakarta: PT. Rosda Karya.

[18] Majid, M. Z. A. (2006). Penghayatan Agama Sebagai Paksi Melayu Glokal. Terengganu Development Institute.

[19] Mansir, F. (2021). Interconnection of Religious Education and Modern Science in Islamic Religious Learning. Edukasi: Jurnal Pendidikan Islam, 9(2), 229-237.

[20] Morgan, J. (2009). An Examination of Thinking Maps in the Context of InquiryBased Science Education for Fifth-Grade Students. United States: New Hampshire.

[21] Muhayat, I. (2020). Discussing the Dialectics of Science on Islamic Education. AlHayat: Journal of Islamic Education, 4(1), 1-18. https://doi.org/10.35723/ajie.v4i1.95

[22] Muhd, A., \& Hasan, A. (2011). 11 Teori dan Prinsip Motivasi di Tempat Kerja. Malaysia: PTS Profesional Publishing SDN. BHD.

[23] Nordin, T. A., \& Dan, N. A. (2002). Pendidikan dan Pembangunan Manusia: Pendekatan Bersepadu. Bangi: As Syabab Media.

[24] Othman, M. F., Noh, M. A. C., Lubis, M. A., \& Hassan, W. N. S. W. (2017). Pendidikan Rohani Berasaskan Sains Al-Quran. ASEAN Comparative Education: Research Journal on Islam and Civilization, 1(1), 64-77.

[25] Othman, M. S., \& Kassim, A. Y. (2017a). Isu Dan Permasalahan (PDP) Perlaksanaan Kemahiran Berfikir Aras Tinggi Dalam Amalan Pengajaran Guru Menurut Pandangan Ibn Khaldun. Journal Of Human Capital Development, 10(1), $1-18$.

[26] Othman, M. S., \& Kassim, A. Y. (2017b). Konsep pengajaran Akidah Kepada Kanak-Kanak Menurut Al-Quran dan Imam Ghazali Berasaskan Kemahiran Berfikir Aras Tinggi. Journal Of Islamic Social Science and Humanities, 10(10), 83-93.

[27] Ramayulis. (2012). Ilmu Pendidikan Islam. Jakarta: Kalam Mulia.

[28] Rashed, Z. N. (2016). Amalan Pengintegrasian Ilmu Sains dan Al-Quran Dalam Pengajaran Pendidikan Islam di Maahad Tahfiz Sains Negeri Selangor. Fakulti Pendidikan. Bangi: UKM.

[29] Rashed, Z. N., Tamuri, A. H., Pisol, M. I., Ilias, M. F., \& Ihwani, S. S. (2016). Peranan Al-Quran Sebagai Sumber Ilmu Pengetahuan Dan Hubungannya Dengan 
Sains. In Proceeding of 5th International Conference on Islamic Education 2016 (ICIEd 2016).

[30] Salleh, K. M., Othman, M. Y. H., Radiman, S., Dakir, J., Tamuri, A. H., Alwi, N. H., ... Badzis, M. (2011). Teachers Concerns Perception and Acceptance toward Tauhidic Science Education. Kyoto Bulletin of Islamic Area Studies, 4-1(2), 124155.

[31] Tamuri, A. H., \& Yusof, N. M. R. N. (2010). Kaedah Pengajaran dan Pembelajaran Pendidikan Islam. Kuala Lumpur: Dewan Bahasa dan Pustaka. 